IJMS 18 (1), 217-238 (2011)

\title{
IMPAK PERBELANJAAN PELANCONG ANTARABANGSA KEPADA EKONOMI MALAYSIA
}

\author{
NORLIDA HANIM MOHD SALLEH ${ }^{1}$ \\ REDZUAN OTHMAN ${ }^{1,2}$ \\ ABDUL HAMID JAAFAR ${ }^{1}$ \\ ${ }^{1}$ Fakulti Ekonomi dan Perniagaan \\ Universiti Kebangsaan Malaysia \\ ${ }^{2}$ Institut Kajian Asia Barat (IKRAB) \\ Universiti Kebangsaan Malaysia
}

\begin{abstract}
Abstrak
Peningkatan perbelanjaan pelancong akan membawa kesan kepada meningkatnya permintaan akhir barangan dan perkhidmatan negara yang dilawati. Keadaan ini mempengaruhi atau memberi kesan kepada peningkatan tingkat keluaran dan pendapatan, serta kutipan cukai kerajaan daripada sektor tersebut. Sesetengah keperluan pelancong merupakan barang akhir atau barangan yang menggunakan asas input yang diimport. Ini bermakna perbelanjaan mereka juga merangsang peningkatan import. Kajian ini membincangkan secara konseptual dan disusuli secara praktikal bagi menganggarkan impak sebenar yang terhasil daripada perbelanjaan pelancong. Bagi tujuan tersebut kaedah Input-Output (I-O) akan digunakan. Untuk menggunakan kaedah ini, Jadual I-O yang dikeluarkan oleh Jabatan Perangkaan Malaysia yang merujuk kepada I-O 2000 telah diagregatkan mengikut kesesuaian kajian. Hasil kajian mendapati beberapa subsektor pelancongan seperti hotel dan restoran, borong dan runcit, pengangkutan serta sektor pembuatan yang bukan merupakan subsektor pelancongan adalah antara sektor utama penjana ekonomi keseluruhan. Nilai pengganda bagi keluaran, pendapatan dan kutipan cukai kerajaan yang dicatatkan berada pada kadar yang memberangsangkan (10-50 peratus). Sungguhpun perbelanjaan pelancongan secara keseluruhan menyebabkan import barang dan perkhidmatan dari luar negara meningkat, namum peningkatan import adalah sekitar 20 peratus sahaja. Hasil kerja ini dapat dijadikan panduan dalam membina polisi pelancongan serta membantu pelajar lebih memahami keterkaitan yang wujud dalam sebuah sistem ekonomi.
\end{abstract}

Kata Kunci: Pelancongan Malaysia, impak ekonomi, pengganda, analisis Input-Output. 


\begin{abstract}
Purpose - The increase in tourist expenditure will lead to increment in the final demand for goods and services from tourism related sub-sectors in the countries they have visited. This increment will affect or cause expansion in national output, income and government tax collections from related sub-sectors. Some of the goods required by tourists are final goods or goods which use imported input base. Since tourists also require imported goods, their spending will definitely stimulate the volume of imported goods. This study discussed the conceptual framework of Input-Output Analysis, and followed by estimating the real impact of international tourist spending to the Malaysian economy.
\end{abstract}

Design/Methodology/Approach - This research employed the InputOutput Analysis. For the purpose of empirical estimation the Input-Output Table 2000 published by the Department of Statistic with appropriate subsectors aggregation was utilized.

Findings - The research findings have shown that several tourism subsectors namely hotels and restaurants, wholesale and retail, transportation as well as the manufacturing sector which is not directly related to the tourism sub-sector are among the important contributors to the economy as a whole. Multiplier values for the output, income and tax collections are quite high (10-50 percent). Although, tourist spending also contributed to the increase in the volume of imports, its increase was relatively low around 20 percent.

Originality/Value - The research results can be used as a guidance by appropriate stakeholders especially in formulating tourism-related policies as well as assisting students to have a better understanding of the interrelatedness of the various economic sectors in any country.

Keywords: Malaysian tourism, economic impact, multipliers, input-output analysis.

\title{
Pengenalan
}

Sungguhpun industri telah agak lama berkembang di Malaysia, namun bermula pertengahan tahun 1980-an barulah pihak kerajaan bertekad untuk membangunkan industri pelancongan secara besarbesaran kesan daripada kemelesetan ekonomi dunia. Keseriusan pihak kerajaan dalam memajukan industri pelancongan ini tercermin dengan penubuhan Kementerian Kebudayaan, Kesenian dan Pelancongan pada tahun 1987 dan kemudiannya kementerian ini dipecahkan kepada Kementerian Pelancongan dan Kementerian 
Kebudayaan, Kesenian dan Warisan pada 2004 bagi membolehkan kerajaan mengendali, menyelaras, mengawal dan memantau kegiatan pelancongan ini secara terfokus.

Bagi menggalakkan pembangunan, pihak kerajaan juga telah memperuntukkan dana yang agak besar kepada industri ini. Misalnya dalam Rancangan Malaysia ke-6 (RMK6) sejumlah RM494.4 juta diperuntukkan kepada industri pelancongan. Dalam RMK7 peruntukan ini meningkat kepada RM605.5 juta, meningkat kepada RM1,009 juta dan RM1,847.9 juta pada RMK8 dan RMK9 (Pelbagai Rancangan Malaysia).

Disamping peruntukan yang besar, pihak kerajaan juga turut menawarkan pelbagai galakan atau insentif kepada pengusaha pelancong bagi menggalakkan penyertaan pengusaha pelancongan persendirian yang layak. Antara skim penggalakan yang diberikan ialah Taraf Perintis, Elaun Cukai Pelaburan, insentif untuk industri kapal mewah, pengecualian cukai (cukai pendapatan dan import), potongan cukai dua kali (untuk latihan dan perbelanjaan luar negeri untuk promosi) dan pelbagai potongan cukai untuk pengusaha pelancongan yang lain (Redzuan \& Norlida, 2006).

Bagi menjalankan usaha-usaha promosi di luar negara yang selalunya memerlukan kos yang tinggi, pihak Pelancongan Malaysia telah membuka pejabatnya di luar negara. Sehingga kini terdapat sebanyak 32 pejabat Pelancongan Malaysia diseluruh dunia untuk mempromosikan Malaysia sebagai destinasi pelancongan (www. tourism.gov.my).

Usaha kerajaan dan pihak pengusaha pelancongan persendirian telah membangunkan industri ini dengan begitu pantas. Hal ini ditunjukkan oleh peningkatan dalam ketibaan pelancong asing dan pendapatan yang disumbangkan seperti ditunjukkan di Jadual 1. Pada tahun 1985 kira-kira 3.1 juta pelancong berkunjung ke Malaysia dengan perolehan pendapatan sebanyak RM1.5 billion. Menjelang tahun 2007 bilangan pelancong yang melawat negara ini meningkat kepada hampir 21 juta dengan penjanaan pendapatan pelancong sejumlah hampir RM46.1 billion. Dalam bentuk pertumbuhan sepanjang 22 tahun lalu (1985-2007), bilangan ketibaan pelancong antarabangsa meningkat secara purata kira-kira 9 peratus setahun manakala pendapatan dari pelancong meningkat kira-kira 17 peratus setahun.

Bagi kebanyakan negara khususnya negara sedang membangun, industri pelancongan merupakan antara penyumbang utama kepada 
perolehan mata wang asing atau eksport. Di Malaysia, industri ini berada pada kedudukan kedua industri utama sebagai penyumbang kepada eksport iaitu di belakang industri pembuatan. Sumbangan industri ini kepada jumlah pendapatan eksport dan pendapatan kasar dalam negeri ialah antara 2-7 peratus, rujuk Jadual 1.

Jadual 1

Prestasi Industri Pelancongan Malaysia 1980-2007

\begin{tabular}{ccccc}
\hline Tahun & \multicolumn{4}{c}{ Pekara } \\
\cline { 2 - 5 } & $\begin{array}{c}\text { Ketibaan } \\
\text { pelancong } \\
(1)\end{array}$ & $\begin{array}{c}\text { Pendapatan dari } \\
\text { pelancong } \\
\text { (RM juta) } \\
(2)\end{array}$ & $\begin{array}{c}\text { Peratusan eksport } \\
\text { daripada industri } \\
\text { pelancongan }(\%)\end{array}$ & $\begin{array}{c}\text { Peratusan GDP } \\
\text { daripada industri } \\
\text { pelancongan }(\%)\end{array}$ \\
\hline 1975 & $1,165,270$ & 389.5 & - & - \\
1980 & $2,067,020$ & 618.9 & 2.1946 & 2.3629 \\
1985 & $3,109,106$ & 1543.1 & 4.0589 & 2.7001 \\
1990 & $7,445,908$ & 4500.0 & 5.0798 & 3.7866 \\
1995 & $7,468,749$ & 9174.9 & 4.6768 & 4.4004 \\
1996 & $7,138,452$ & 10354.1 & 4.8151 & 4.4094 \\
1997 & $6,210,921$ & 9699.0 & 2.6678 & 2.4888 \\
1998 & $5,550,748$ & 8580.0 & 2.6204 & 3.0329 \\
1999 & $7,931,149$ & 13450.0 & 3.3765 & 4.0961 \\
2000 & $10,221,582$ & 17335.4 & 4.0598 & 5.0598 \\
2001 & $12,775,073$ & 24221.5 & 6.2224 & 7.2452 \\
2002 & $13,292,010$ & 25781.1 & 6.2679 & 7.1496 \\
2003 & $10,576,915$ & 21291.1 & 5.7000 & 5.7280 \\
2004 & $15,703,406$ & 29651.4 & 7.0000 & 7.0081 \\
2005 & 16,431055 & $31,954.1$ & 6.4400 & 6.4500 \\
2006 & $17,546,863$ & $36,271.7$ & 6.7600 & 6.8000 \\
\hline
\end{tabular}

Sumber. Ubah suai daripada ASEAN Statistical Year Book, 2003 at www.aseansec.org, WTO, 19902000, World Bank, World Development Indicator 2004,2008, dan Malaysia Economic Report, 2005.

Di sini jelas menunjukkan industri pelancongan mampu menjadi penyumbang pendapatan eksport yang penting kepada ekonomi negara. Sumbangan ini pula pastinya membawa impak yang lebih besar kepada keseluruhan ekonomi Malaysia melalui kesan limpahan. Keadaan ini berlaku kerana terdapat pelbagai sub sektor yang berkaitan antara satu dengan yang lain dalam industri pelancongan. Malah terdapat beberapa sektor di luar daripada industri pelancongan yang berkait secara tidak langsung dengan industri pelancongan ini. Keadaan ini menggambarkan pembangunan dan pertumbuhan dalam sektor pelancongan sama ada secara langsung atau tidak langsung membawa pertumbuhan kepada sektor-sektor 
lain disebabkan oleh kewujudan rantaian antara sektor. Natijahnya, ia akan membawa kesan pembangunan dan pertumbuhan yang lebih besar kepada ekonomi negara secara keseluruhan.

Kertas kerja ini cuba menganggarkan impak yang terhasil daripada pertumbuhan industri pelancongan yang diwakili oleh peningkatan perbelanjaan pelancong. Antara objektif kajian adalah untuk menganggarkan impak perbelanjaan pelancong asing terhadap tambahan dalam: i) output, ii) pendapatan, iii) hasil cukai dan iv) import. Untuk tujuan ini analisis Input-Output (I-O) akan digunakan dengan menggunapakai Jadual I-O Malaysia tahun 2000. Perbincangan kertas kerja ini terdiri daripada beberapa bahagian iaitu: Metodologi; Kerangka Dasar Analisis Impak Ekonomi daripada Industri Pelancongan; Sorotan Kajian Lepas; Analisis Model InputOutput dan Sumber Data; Analisis Keputusan Empirikal; Implikasi Dasar dan Kesimpulan.

\section{Metodologi: Kerangka Asas Analisis Impak Ekonomi daripada Industri Pelancongan}

Umumnya, analisis kesan ekonomi menganggarkan perubahan dalam ekonomi yang disebabkan oleh kesan daripada beberapa tindakan di dalam sesuatu kawasan (Archer, 1989). Analisis kesan merupakan satu pendekatan ekonomi yang digunakan untuk mengukur perubahan dalam jumlah pendapatan, hasil kerajaan, pekerjaan dan import yang dijana dalam ekonomi akibat perubahan dalam permintaan akhir.

Bagi kes industri pelancongan sebagaimana kajian ini, permintaan akhir merujuk kepada peningkatan dalam perbelanjaan yang dilakukan oleh pelancong. Peningkatan ini menyebabkan lebih banyak barangan dan perkhidmatan yang diminta khusus dalam sektor-sektor yang berkaitan dengan pelancongan. Peningkatan dalam permintaan ini mesti diimbangi dengan penawaran output. Oleh itu, didapati bahawa peningkatan perbelanjaan ini secara langsungnya telah meningkatkan output dalam ekonomi. Dengan itu pendapatan juga akan meningkat, begitu juga dengan hasil kerajaan melalui cukai dan import sekiranya penawaran barangan dan perkhidmatan tersebut adalah berasaskan kepada sumber bahan yang diimport.

Jelas di sini, tindakan atau perubahan yang berlaku dalam sesebuah ekonomi (perbelanjaan pelancong) akhirnya membawa kesan yang banyak kepada ekonomi negara. Kesan ini bukan sahaja dinikmati 
oleh sektor yang berkaitan langsung dengannya tetapi juga akan melimpah kepada sektor lain akibat daripada berlakunya kesan limpahan. Ini kerana dalam sebuah sistem ekonomi yang lengkap, setiap sektor adalah saling berkait antara satu dengan yang lain. Oleh itu, kesan keseluruhan kepada ekonomi akibat daripada perbelanjaan pelancong akan meningkatkan dengan lebih besar lagi. Dari segi terminologinya, kesan keseluruhan kepada ekonomi ini adalah terjana melalui kesan langsung dan kesan sekunder (kesan tidak langsung dan kesan penyebab/teraruh) daripada perbelanjaan pelancong.

Kesan langsung adalah perubahan dalam industri yang berhubung secara langsung dengan perbelanjaan pelancong. Contohnya: pelancong yang berbelanja $\$ 100$ untuk penginapan akan meningkatkan jualan dan pendapatan dalam sektor perhotelan sejumlah ini. Ini adalah kesan langsung daripada perbelanjaan pelancong.

Kesan tidak langsung adalah kesan daripada urus niaga pusingan kedua (kali ke-2) yang dibuat oleh pihak hotel dengan industriindustri lain yang diperlukan perkhidmatannya oleh pelancong. Berasaskan contoh di atas pihak hotel seterusnya akan menggunakan wang yang diperoleh daripada pelancong ini untuk mengupah pekerja dan membayar gaji sekaligus mencipta peluang pekerjaan yang akan menambahkan pendapatan. Misalnya, hotel perlu membeli bekalan makanan daripada industri lain untuk melengkapkan perkhidmatan kepada pelanggannya. Di pihak syarikat pembekal makanan pula, mereka juga perlu membeli bahan-bahan mentah seperti sayursayuran, buah-buahan dan sebagainya daripada industri lain supaya dapat memenuhi permintaan daripada pihak hotel tadi. Jualan yang wujud antara industri ini (hotel dan pembekal makanan) adalah kesan tidak langsung. Kesan tidak langsung ini merupakan urus niaga seterusnya selepas kesan langsung tetapi masih lagi berkaitan dengan sektor pelancongan.

Kesan penyebab/teraruh wujud hasil daripada perbelanjaan isi rumah yang mana pendapatan yang mereka peroleh adalah kesan daripada perbelanjaan pelancongan sama ada secara langsung atau tidak langsung. Untuk kesan teraruh, perbelanjaan oleh mereka yang memperoleh pendapatan daripada pelancongan tidak dibuat untuk urus niaga yang berkaitan dengan pelancongan tetapi perbelanjaan mereka ini secara keseluruhan meningkatkan jualan, pendapatan dan penciptaan guna tenaga keseluruhan dalam ekonomi. Pekerja di sektor perhotelan sebagai isi rumah misalnya sudah pasti menggunakan pendapatan mereka (daripada perbelanjaan pelancongan) untuk 
tujuan yang tiada kaitannya dengan pelancongan seperti perbelanjaan makanan, pendidikan, kesihatan dan sebagainya.

Di setiap peringkat perbelanjaan seterusnya akan mengurangkan jumlah wang yang boleh digunakan dalam perbelanjaan di sesuatu kawasan/negara berkenaan melalui kegiatan tabungan dan import. Melalui kegiatan tabungan dan import ini jumlah wang yang beredar dalam sistem perbelanjaan seterusnya akan berkurangan. Wang yang terkeluar daripada sistem ini melalui tabungan dan import ini dikenali sebagai kesan bocoran.

Jelasnya, perbelanjaan para pelancong mempunyai kesan tambahan yang signifikan kepada seluruh ekonomi. Perbelanjaan pelancong akan menyebabkan peningkatan dalam pendapatan dan perbelanjaan oleh kumpulan isi rumah yang luas, tetapi tidak semestinya berhubung secara langsung dengan pelancongan. Kesan keseluruhan daripada proses perbelanjaan dan perbelanjaan semula ini dikenali sebagai kesan pengganda. Kesan pengganda menggambarkan perubahan terakhir dalam output dan merupakan pengukuran kesan ekonomi daripada aktiviti pelancongan (Archer, 1982). Semakin besar nilai pengganda semakin besar kesan satu unit perbelanjaan pelancong ke atas ekonomi sesebuah negara/kawasan.

Terdapat beberapa pendekatan yang boleh digunakan untuk analisis kesan ekonomi ini. Antaranya adalah analisis Input-Output (IO) dan Computable General Equilibrium (CGE). Sungguhpun para penyelidik kebelakangan ini kerap menggunakan kaedah CGE, namun penggunaan kaedah ini lebih bertujuan untuk melihat perubahan-perubahan yang berlaku dalam ekonomi akibat daripada kejutan-kejutan dasar yang dilakukan. Sedangkan kajian ini ingin menganggarkan impak perbelanjaan pelancong asing ke Malaysia. Maka adalah lebih sesuai menggunakan pendekatan I-O. Ini kerana kaedah ini dapat melihat kesan dan saling keterkaitan antara sektor. Analisis I-O walaupun pada asasnya mengandaikan bahawa nilai teknikal koefisien tidak berubah (terlalu kecil) dan ini dianggap sebagai kelemahan kepada kaedah ini, namun didapati masih relevan dan memenuhi keperluan semasa dan digunakan oleh kebanyakan penyelidik sehingga kini dan dapat memenuhi objektif kajian.

\section{Sorotan Kajian Lepas}

Penggunaan kaedah I-O dalam kajian impak pelancongan kepada ekonomi mula mendapat perhatian selepas kajian yang dilakukan oleh Harmston (1969) di Missouri Amerika Syarikat. Penganggaran 
yang paling utama dan mendapat perhatian kebanyakan penyelidik adalah penentu pengganda perbelanjaan pelancong (Sinclair, 1998). Seperti dinyatakan di bahagian sebelum ini, sungguhpun terdapat sedikit kelemahan, namun kaedah I-O masih relevan digunakan oleh penyelidik seperti kajian oleh Summary (1987); Fletcher (1989); Archer (1995); Archer and Fretcher (1996); Henry dan Deany (1997); Frechtling and Horvath (1999); Surendra (2000); Kweka, Morrisey dan Blake et al. (2003); Zakariah dan Bashir, (2004); Mohammmad, Elsadiq \& Abul Quasem (2009), dan ramai lagi. Pendekatan yang digunakan oleh kebanyakan penyelidik adalah hampir sama sementara hal yang membezakan adalah skop kajian setiap penyelidik.

Kweka et al. (2003) umpamanya menggunakan kaedah yang sama bagi kajian ke atas ekonomi Tanzania. Kajian ini hanya memberi penekanan terhadap hotel dan restoran sebagai subsektor bagi pelancongan. Hasil kajian beliau mendapati bahawa kedua-dua sektor ini memperoleh perbelanjaan tinggi para pelancong.

Sementara Surendra (2000) pula mengkaji corak perbelanjaan pelancong dan komposisi sumber tempatan dalam penggunaan oleh pelancong dan kesannya terhadap guna tenaga di Nepal. Dengan menggunakan kaeedah I-O model tertutup, kajian ini mendapati bahawa perbelanjaan pelancong kebanyakan dibelanjakan untuk penginapan dan perjalanan termasuk tambang penerbangan. Kajian ini turut mendapati pengganda import adalah tinggi bagi industri pelancongan Nepal.

Henry dan Deany (1997), turut menggunakan kaedah I-O bagi kajian beliau di Ireland. Dengan membenarkan kesan induced dari kerajaan dan isi rumah, kajian ini mendapati kesan perbelanjaan pelancong adalah lebih besar terhadap pendapatan negara (GNP) berbanding eksport.

Archer (1995) dalam kajian di Bemuda mendapati kesan terhadap guna tenaga adalah signifikan. Selain mencatatkan berlakunya peningkatan dalam pengganda pendapatan disebabkan oleh peningkatan dalam nilai ditambah sektor-sektor dalam ekonomi.

Summary (1987) pula mendapati melalui penggunaan keadah I-O yang standard ini, kesan keterkaitan antara sektor adalah tinggi, tetapi kesan kepada pendapatan dan guna tenaga adalah rendah kerana tingkat upah gaji masyarakat Kenya yang pada puratanya adalah rendah. 
Begitu juga kajian yang dilakukan di Malaysia, umpamanya oleh Zakariah dan Bashir (2004). Kajian ini mengkaji impak terhadap ekonomi akibat daripada perubahan corak perbelanjaan dan profil pelancong bagi tahun 2000 dan 2001. Walau bagaimanapun, dengan menggunakan Jadual I-O 1991 tentunya anggaran yang dilakukan adalah kurang tepat terutama bagi anggaran pendapatan dan gunatenaga.

Memperbaiki kajian ini Mohammad et al. (2009) juga melakukan kajian yang sama bagi kes Malaysia tetapi menggunakan kaedah I-O tertutup. Seperti kajian pelancongan di Nepal, bocoran tetap berlaku dalam industri pelancongan Malaysia namun pada kadar yang lebih rendah. Bagi penjanaan keluaran, pengganda bagi sektor utama yang berkaitan dengan pelancongan seperti makanan dan minuman, penginapan, pengangkutan dan membeli-belah serta hiburan adalah sederhana. Sementara pengganda guna tenaga dicatatkan pada nilai yang lebih rendah. Begitu juga dengan nilai-nilai pengganda yang lain seperti pengganda pekerjaan dan nilai ditambah.

Kajian yang dilakukan ini tidak banyak bezanya dengan dua kajian yang dilakukan oleh Zakariah dan Bashir (2004) dan Mohammad et al. (2009) mahupun kajian oleh Kweka et al. (2003) dan Surendra (2000). Kajian ini meneliti impak daripada peningkatan perbelanjaan pelancongan asing terhadap pelbagai sektor dalam ekonomi Malaysia secara makro. Kajian ini memberikan tumpuan kepada pelancong asing sahaja kerana data mengenai bilangan pelancong domestik dan perbelanjaan mereka agak sukar diperoleh. Yang membezakan kajian ini dengan dua kajian di Malaysia yang dibincangkan adalah dari sudut penggunaan data I-O yang diterbitkan (I-O 2000) dan pengagregatan sektoral yang terlibat.

\section{Analisis Model Input-Output dan Sumber Data}

Penggunaan kaedah I-Ountuk mengukur impak industri pelancongan kepada ekonomi keseluruhan telah dilakukan oleh ramai penyelidik seperti mana dibincangkan di bahagian yang lepas. Analisis ini adalah satu kaedah penjadualan sistem ekonomi dalam bentuk matrik melalui Jadual Input Output. Sistem bacaannya adalah secara baris dan lajur/kolum. Baris menunjukkan penjualan hasil atau output oleh sektor i kepada sektor-sektor lain iaitu sektor j. Sementara bacaan secara lajur/kolum menunjukkan pembelian atau penggunaan input oleh sektor j daripada sektor-sektor lain iaitu i. 
Cara bacaan ini jelas menunjukkan terdapatnya hubungan atau rantaian antara satu sektor dengan sektor yang lain dalam sistem sesebuah ekonomi. Hal ini bermakna terdapat rantaian antara satu subsektor dengan subsektor lain dalam pelancongan itu sendiri di samping rantaiannya dengan sektor-sektor yang lain dalam ekonomi. Rantaian seperti ini akan membawa impak kepada ekonomi keseluruhannya. Dalam kaedah I-O, analisis impak pelancongan kepada sektor lain adalah berlaku apabila berlakunya perubahan dalam perbelanjaan pelancong seperti dinyatakan dalam perbincangan di atas.

\section{Model Input-Output}

Model I-O secara ringkas adalah seperti ditunjukkan di Persamaan (1):

$$
\mathrm{X}-\mathrm{AX}=\mathrm{F}
$$

dengan $\mathbf{X}$ dan $\mathbf{F}$ adalah masing-masing vektor bagi output dan permintaan akhir. Sementara A adalah matrik koefisien teknikal. Dengan memasukkan matrik identiti (I) ke dalam persamaan, Persamaan (1) menjadi Persamaan (2) atau (3).

$$
\text { (I - A) } \mathrm{X}=\mathrm{F}
$$

atau

$$
\mathrm{X}=(\mathrm{I}-\mathrm{A})^{-1} \mathbf{F}
$$

dengan (I-A) $)^{-1}$ adalah Matrik Songsang yang juga dikenali sebagai koefisien matrik saling pergantungan antara industri (Interindustry Interdependence Coefficient Matrix). Elemen dalam matrik ini menunjukkan pembelian input oleh suatu industri daripada industri lain untuk menghasilkan seunit output akibat peningkatan dalam permintaan akhir. Hasil darab antara matrik ini dengan vektor permintaan akhir (F) akan menghasilkan/menunjukkan output kepada negara $(\mathbf{X})$. Oleh itu, secara tidak langsung matrik ini juga menunjukkan kesan pengganda (multiplier effect).

Dengan menggunakan perbelanjaan pelancong pada tahun 2006, anggaran impak industri pelancongan terhadap output sesuatu sektor dapat dilakukan dengan mendarabkan vektor permintaan pelancong dengan Matrik Songsang Leontif tersebut seperti persamaan (3). 
Impak perbelanjaan pelancong terhadap pendapatan, hasil cukai dan import pula masing-masing ditunjukkan oleh Persamaan (4), (5) dan (6) di bawah.

$$
\mathbf{P N D}=\hat{W}(\mathbf{I}-\mathbf{A})^{-1} \mathbf{F}
$$

dengan PND adalah pendapatan dan $\mathrm{W}$ adalah koefisien pepenjuru (diagonal coefficients) pendapatan buruh ${ }^{1}$ daripada setiap sektor.

$$
\mathrm{HC}=\hat{C}(\mathbf{I}-\mathbf{A})^{-1} \mathbf{F}
$$

dengan HC adalah hasil dan C koefisyen pepenjuru (diagonal coefficients) cukai daripada setiap sektor. Cukai terbahagi kepada dua iaitu cukai bagi barangan dan perkhidmatan dalam input primer yang diimport dan dari pasaran domestik.

$$
\mathrm{IMP}=\hat{M}(\mathrm{I}-\mathbf{A})^{-1} \mathbf{F}
$$

dengan IMP adalah import dan M koefisien pepenjuru (diagonal coefficients) import daripada setiap sektor.

\section{Sumber Data}

Data penting yang diperlukan dalam kajian ini adalah data perbelanjaan pelancong dan Jadual I-O Malaysia. Data perbelanjaan pelancong bagi Malaysia diperoleh daripada Soal selidik Kementerian Pelancongan Malaysia pada tahun 2006 sementara Jadual I-O adalah Jadual I-O 2000 dari Jabatan Perangkaan Malaysia.

Untuk mencapai tujuan kajian, perbelanjaan pelancong yang dirujuk sebagai permintaan akhir (F) dalam kajian ini diagihkan kedalam beberapa subsektor iaitu hotel dan restoran, pengangkutan, hiburan, rekreasi, dan membeli belah (diproksi sebagai perdagangan borong dan runcit). Untuk tujuan analisis impak, Jadual I-O 2000 yang merupakan jadual 94 X 94 sektor diagregatkan kepada jadual 18 X 18 sektor. Klasifikasi pengagregatan adalah mengikut klasifikasi oleh International Standard of Industrial Classification of All Economic Activities (United Nation, 1999) yang juga digunapakai oleh Jabatan Perangkaan Malaysia 2000.

Pengagregatan kepada berapa jumlah sektor pada umumnya adalah bergantung kepada objektif kajian yang ingin di capai. Dalam kajian 
ini, pengagregatan kepada 18 sektor sahaja adalah mengikut sektorsektor utama ekonomi Malaysia seperti sektor pertanian, pemburuan dan perhutanan; perikanan; perlombongan dan kauri; pembuatan; elektrik, gas dan bekalan air; pembinaan; komunikasi; kewangan; harta tanah, sewaan dan aktiviti perniagaan; pendidikan; kesihatan dan kebajikan sosial; perkhidmatan persendirian serta pertahanan dan pentadbiran awam ${ }^{2}$. Di samping memberi keutamaan menonjol sektor yang berhubung secara langsung dengan sektor pelancongan seperti borong dan runcit; hotel dan restoran; pengangkutan; hiburan serta rekreasi.

\section{Analisis Keputusan Empirikal}

Dalam tahun 2006 seperti ditunjukkan di Jadual 1, Malaysia menerima hampir 18 juta pelancong asing dengan pendapatan pelancong sejumlah RM36.3 billion. Dengan tempoh tinggal di Malaysia secara purata sekitar 6.2 malam bermakna pelancong ini telah berbelanja secara purata sebanyak RM332.7 selama berada di Malaysia, atau dalam per kapita adalah sebanyak RM2,067.1. Daripada jumlah ini sebahagian besar perbelanjaan digunakan perbelanjaan penginapan (31\%), diikuti oleh membeli-belah (22\%), makanan (17\%), pengangkutan (15\%), hiburan (6\%), dan rekreasi dan lain lain $(7 \%)$. Perbelanjaan pelancong terhadap item ini secara umumnya telah meningkatkan atau memberi impak bukan sahaja kepada subsektor dalam industri pelancong ini sahaja tetapi kepada semua sektor yang berkaitan dengannya secara langsung atau tidak langsung.

\section{a. Impak terhadap Output}

Jadual 2 menunjukkan impak perbelanjaan pelancong terhadap output sektor pelancongan dan sektor-sektor lain. Daripada jadual, pada tahun 2006 perbelanjaan pelancong sebanyak RM36,271.7 juta ini telah meningkatkan output sektor pelancongan sebanyak RM37,515.8 juta akibat kesan pengganda. Di samping terdapat juga kesan limpahan ke atas sektor-sektor lain sebanyak RM17,509.12 juta.

Maklumat yang ditunjukkan dalam Jadual 2 jelas menunjukkan perbelanjaan yang dilakukan oleh pelancong bukan sahaja memberi impak kepada sektor pelancongan itu sendiri malahan juga sektor sektor lain. Secara lebih terperinci keseluruhan peningkatan output kesan perbelanjaan pelancong didominasikan oleh beberapa subsektor pelancongan penting iaitu hotel dan restoran $(37.71 \%)$, borong dan runcit $(20.56 \%)$, pembuatan $(13.10 \%)$, pengangkutan $(11.04 \%)$ dan pertanian, pemburuan dan perhutanan $(2.88 \%)$. 
Jadual 2

Impak Industri Pelancongan terhadap Output

\begin{tabular}{|c|c|c|c|c|c|c|c|}
\hline \multirow{2}{*}{ 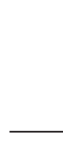 } & \multirow{2}{*}{$\begin{array}{l}\text { Sektor/Industri dalam } \\
\text { ekonomi }\end{array}$} & \multicolumn{6}{|c|}{ Kesan terhadap output (RM Juta) } \\
\hline & & Langsung & $(\%)$ & $\begin{array}{c}\text { Tidak } \\
\text { langsung }\end{array}$ & $(\%)$ & Keseluruhan & $(\%)$ \\
\hline 1 & $\begin{array}{l}\text { Pertanian, pemburuan dan } \\
\text { perhutanan }\end{array}$ & 0 & - & $1,584.05$ & 9.05 & $1,584.05$ & 2.88 \\
\hline 2 & Perikanan & 0 & - & $1,096.23$ & 6.26 & $1,096.23$ & 1.99 \\
\hline 3 & Perlombongan dan kuari & 0 & - & 322.46 & 1.84 & 322.46 & 0.59 \\
\hline 4 & Pembuatan & 0 & - & $7,210.76$ & 41.18 & $7,210.76$ & 13.10 \\
\hline 5 & $\begin{array}{l}\text { Elektrik, gas dan bekalan } \\
\text { air }\end{array}$ & 0 & - & $1,469.69$ & 8.39 & $1,469.69$ & 2.67 \\
\hline 6 & Pembinaan & 0 & - & 386.24 & 2.21 & 386.24 & 0.70 \\
\hline 7 & Borong dan runcit & $9,900.65$ & 26.39 & $1,410.22$ & 8.05 & $11,310.88$ & 20.56 \\
\hline 8 & Hotel dan restoran & $20,029.4$ & 53.39 & 719.00 & 4.11 & $20,748.44$ & 37.71 \\
\hline 9 & Pengangkutan & $5,442.89$ & 14.51 & 631.87 & 3.61 & $6,074.76$ & 11.04 \\
\hline 10 & Komunikasi & 0 & - & 725.237 & 4.14 & 725.24 & 1.32 \\
\hline 11 & Kewangan & 0 & - & 295.835 & 1.69 & 295.84 & 0.54 \\
\hline 12 & $\begin{array}{l}\text { Harta tanah, sewaan dan } \\
\text { aktiviti perniagaan }\end{array}$ & 0 & - & $1,359.11$ & 7.76 & $1,359.11$ & 2.47 \\
\hline 13 & Pendidikan & 0 & - & 8.16309 & 0.05 & 8.16 & 0.01 \\
\hline 14 & $\begin{array}{l}\text { Kesihatan dan kebajikan } \\
\text { sosial }\end{array}$ & 0 & - & 7.28257 & 0.04 & 7.28 & 0.01 \\
\hline 15 & Hiburan & $1,390.35$ & 3.71 & 26.26 & 0.15 & $1,416.61$ & 2.57 \\
\hline 16 & Rekreasi & 752.5 & 2.01 & 15.00 & 0.09 & 767.50 & 1.39 \\
\hline 17 & Perkhidmatan persendirian & 0 & - & 185.806 & 1.06 & 185.81 & 0.34 \\
\hline 18 & $\begin{array}{l}\text { Pertahanan dan } \\
\text { pentadbiran awam }\end{array}$ & 0 & - & 55.8861 & 0.32 & 55.89 & 0.10 \\
\hline $\mathrm{Ju}$ & mlah & $37,515.8$ & 100 & $17,509.12$ & 100 & $55,024.95$ & 100 \\
\hline
\end{tabular}

\section{b. Impak terhadap Pendapatan Buruh}

Impak perbelanjaan pelancong terhadap tambahan pendapatan buruh sektor pelancongan dan sektor-sektor lain pula diberikan di Jadual 3. Secara keseluruhannya, perbelanjaan yang dilakukan oleh pelancong pada tahun 2006 telah menjana pertambahan pendapatan sebanyak RM6,642.87 juta. Daripada jumlah ini sejumlah RM5,000.98 juta merupakan kesan tambahan pendapatan langsung daripada

IJMS 18 (1), 217-238 (2011) 229 
sektor yang berkait rapat dengan sektor pelancongan, sementara sejumlah RM1,641.89 merupakan janaan tambahan pendapatan secara tidak langsung.

Jadual 3

Impak Industri Pelancongan terhadap Pendapatan

\begin{tabular}{|c|c|c|c|c|c|c|c|}
\hline & \multirow{2}{*}{$\begin{array}{l}\text { Sektor/Industri dalam } \\
\text { ekonomi }\end{array}$} & \multicolumn{6}{|c|}{ Kesan terhadap pendapatan (RM Juta) } \\
\hline & & Langsung & $(\%)$ & $\begin{array}{l}\text { Tidak } \\
\text { langsung }\end{array}$ & $(\%)$ & Jumlah & $(\%)$ \\
\hline 1 & $\begin{array}{l}\text { Pertanian, pemburuan dan } \\
\text { perhutanan }\end{array}$ & 0.00 & - & 170.918 & 10.41 & 170.918 & 2.57 \\
\hline 2 & Perikanan & 0.00 & - & 116.205 & 7.08 & 116.205 & 1.75 \\
\hline 3 & Perlombongan dan kuari & 0.00 & - & 8.76733 & 0.53 & 8.76733 & 0.13 \\
\hline 4 & Pembuatan & 0.00 & - & 416.782 & 25.38 & 416.782 & 6.27 \\
\hline 5 & $\begin{array}{l}\text { Elektrik, gas dan bekalan } \\
\text { air }\end{array}$ & 0.00 & - & 78.641 & 4.79 & 78.641 & 1.18 \\
\hline 6 & Pembinaan & 0.00 & - & 80.3543 & 4.89 & 80.3543 & 1.21 \\
\hline 7 & Borong dan runcit & $14,33.23$ & 28.66 & 204.145 & 12.43 & $1,637.37$ & 24.65 \\
\hline 8 & Hotel dan restoran & $2,557.35$ & 51.14 & 91.8018 & 5.59 & $2,649.15$ & 39.88 \\
\hline 9 & Pengangkutan & 819.178 & 16.38 & 95.0987 & 5.79 & 914.277 & 13.76 \\
\hline 10 & Komunikasi & 0.00 & - & 81.367 & 4.96 & 81.367 & 1.22 \\
\hline 11 & Kewangan & 0.00 & - & 57.6053 & 3.51 & 57.6053 & 0.87 \\
\hline 12 & $\begin{array}{l}\text { Harta tanah, sewaan dan } \\
\text { aktiviti perniagaan }\end{array}$ & 0.00 & - & 167.852 & 10.22 & 167.852 & 2.53 \\
\hline 13 & Pendidikan & 0.00 & - & 6.20996 & 0.38 & 6.20996 & 0.09 \\
\hline 14 & $\begin{array}{l}\text { Kesihatan dan kebajikan } \\
\text { sosial }\end{array}$ & 0.00 & - & 3.10935 & 0.19 & 3.10935 & 0.05 \\
\hline 15 & Hiburan & 110.951 & 2.22 & 2.0959 & 0.13 & 113.047 & 1.70 \\
\hline 16 & Rekreasi & 80.2745 & 1.61 & 1.60045 & 0.10 & 81.875 & 1.23 \\
\hline 17 & Perkhidmatan persendirian & 0.00 & - & 31.1017 & 1.89 & 31.1017 & 0.47 \\
\hline 18 & $\begin{array}{l}\text { Pertahanan dan } \\
\text { pentadbiran awam }\end{array}$ & 0.00 & - & 28.2402 & 1.72 & 28.2402 & 0.43 \\
\hline Jum & & $5,000.98$ & 100 & 1641.89 & 100 & $6,642.87$ & 100 \\
\hline
\end{tabular}

Pecahan mengikut sektor memperlihatkan bahawa tambahan pendapatan buruh juga adalah didominasikan oleh sektor tiga sektor utama pelancongan iaitu hotel dan restoran, borong dan runcit serta pengangkutan dengan peratusan masing-masing adalah 39.88 peratus, 24.65 peratus dan 13.76 peratus. Sementara sektor pembuatan

230 IJMS 18 (1), 217-238 (2011) 
serta pertanian, pemburuan dan perhutanan pula merupakan sektor yang menunjukkan kesan tambahan pendapatan yang tinggi jika dibandingkan dengan sektor-sektor lain yang berada di luar daripada sektor pelancongan, rujuk Jadual 3.

\section{c. Impak terhadap Hasil Cukai}

Perbincangan sebelum ini telah menjelaskan hasil cukai terbahagi kepada hasil cukai domestik dan hasil cukai import. Keputusan empirikal bagi kedua-dua hasil cukai dipaparkan seperti di Jadual 4. Hasil cukai domestik yang diperoleh kerajaan masih daripada sektor yang terlibat dengan pelancongan iaitu hotel dan restoran (33.25\%), borong dan runcit $(23.42 \%)$, hiburan $(8.66 \%)$, dan pengangkutan $(8.24 \%)$. Sektor-sektor lain adalah terdiri daripada sektor harta tanah, sewaan dan aktiviti perniagaan $(7.99 \%)$ dan sektor pembuatan (7.67\%).

Sementara hasil cukai import pula, tambahan hasil cukai adalah daripada tiga sektor utama iaitu hotel dan restoran (38.42\%), pembuatan $(28.76 \%)$ dan pengangkutan $(20.66 \%)$. Lain-lain sektor hanya menyumbang kepada peratusan yang kecil sahaja dari segi tambahan hasil cukai iaitu kurang daripada 3 peratus.

Secara keseluruhannya, sektor hotel dan restoran masih menjadi penyumbang hasil cukai bagi kerajaan dengan peratusan sebanyak 34.56 peratus. Ini diikuti oleh sektor borong dan runcit $(17.92 \%)$, pembuatan $(13.03 \%)$, pengangkutan $(11.39 \%)$, serta hiburan $(6.65 \%)$ dan harta tanah, sewaan dan aktiviti perniagaan (6.07\%). Sektor-sektor lain hanya menyumbang kurang daripada 3 peratus. Perbelanjaan pelancong pada keseluruhan mencatatkan hasil cukai bagi kerajaan sejumlah RM521.57 juta.

\section{d. Impak terhadap Import}

Sebahagian daripada keperluan barangan dan perkhidmatan pelancong tidak dapat disediakan dari dalam negara. Barangan ini perlu diimport. Kegiatan pengimportan ini menyebabkan berlakunya bocoran dalam sistem ekonomi. Kesan perbelanjaan pelancong terhadap import barangan dan perkhidmatan pula ditunjukkan seperti di Jadual 5. Keseluruhannya sejumlah RM10,679.9 barangan import diperlukan untuk memenuhi keperluan pelancong. Daripada jumlah ini sejumlah RM6,290.9 adalah kesan langsung dan selebihnya RM4,389 adalah secara tidak langsung. Kalau dibandingkan dengan Jadual 2, kesan bocoran keseluruhan output industri pelancongan Malaysia adalah hampir 20 peratus. 


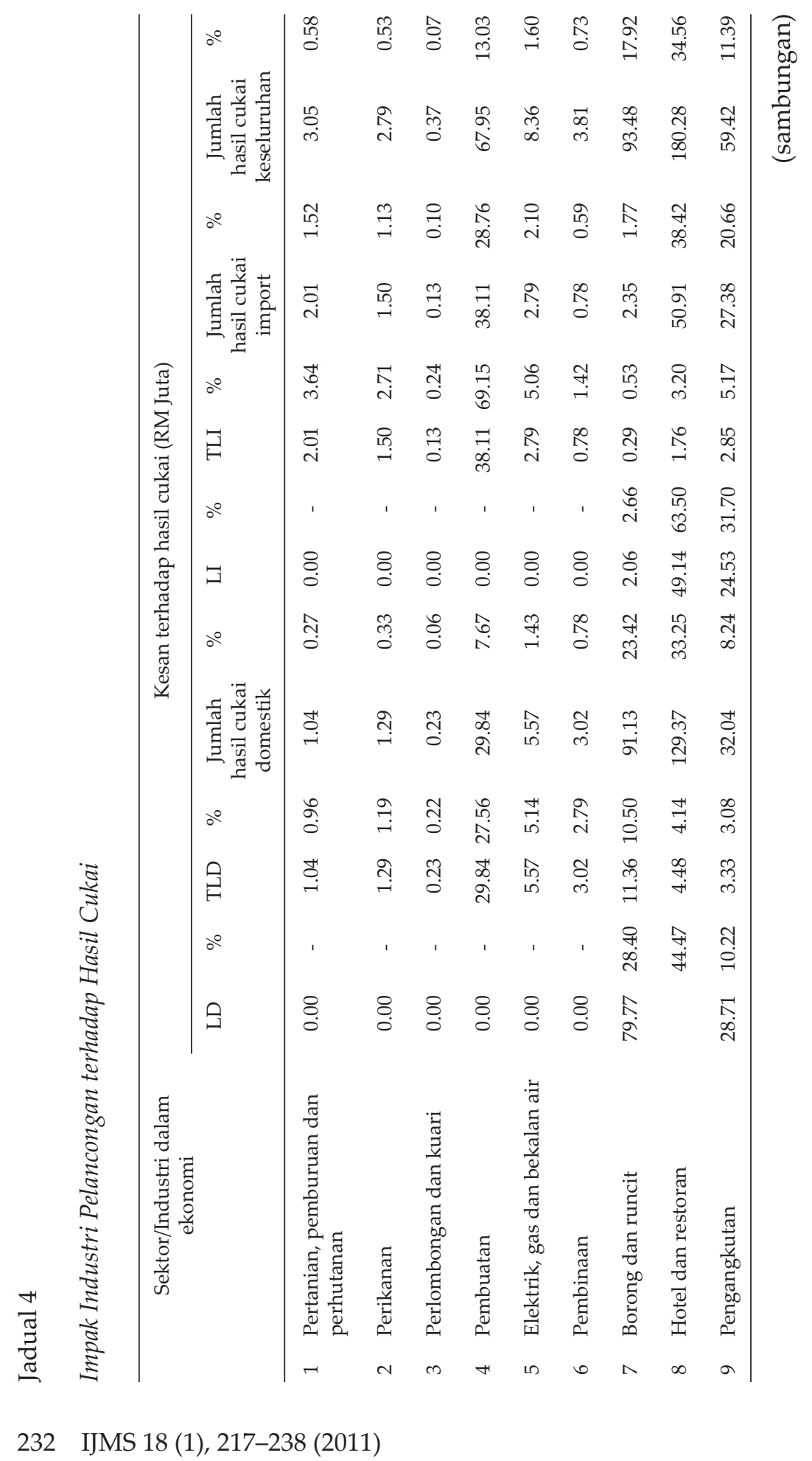




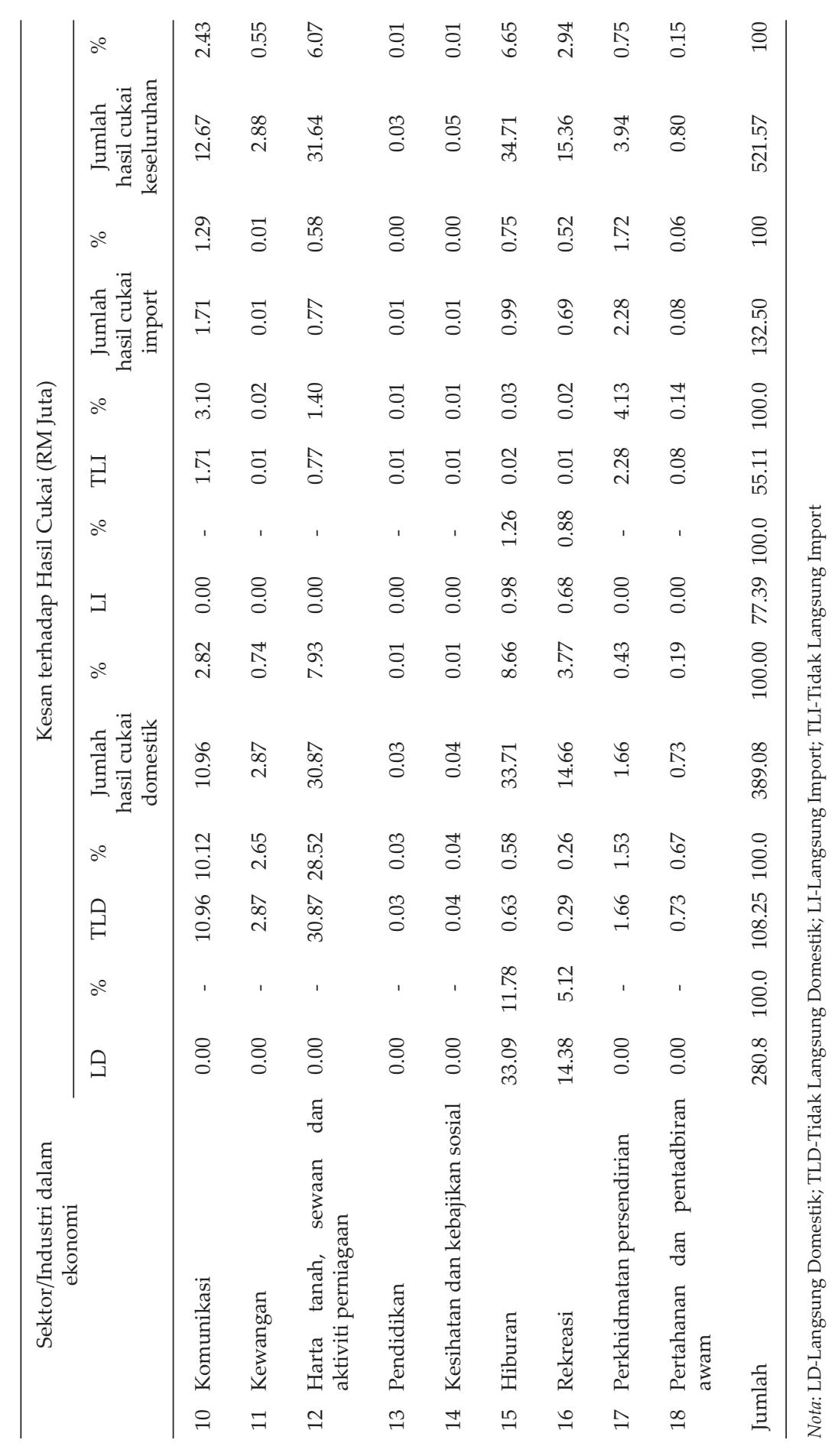

IJMS 18 (1), 217-238 (2011) 233 
Jadual 5 menunjukkan tambahan import yang ketara berlaku dalam sektor hotel dan restoran $(37.40 \%)$, pembuatan $(29.58 \%)$, pengangkutan $(14.35 \%)$, serta borong dan runcit (10.38\%). Import bagi kegunaan sektor lain berada pada paras yang rendah iaitu dengan janaan tambahan import pada kadar antara 0.01 peratus -1.43 peratus sahaja.

Jadual 5

Impak Industri Pelancongan terhadap Import

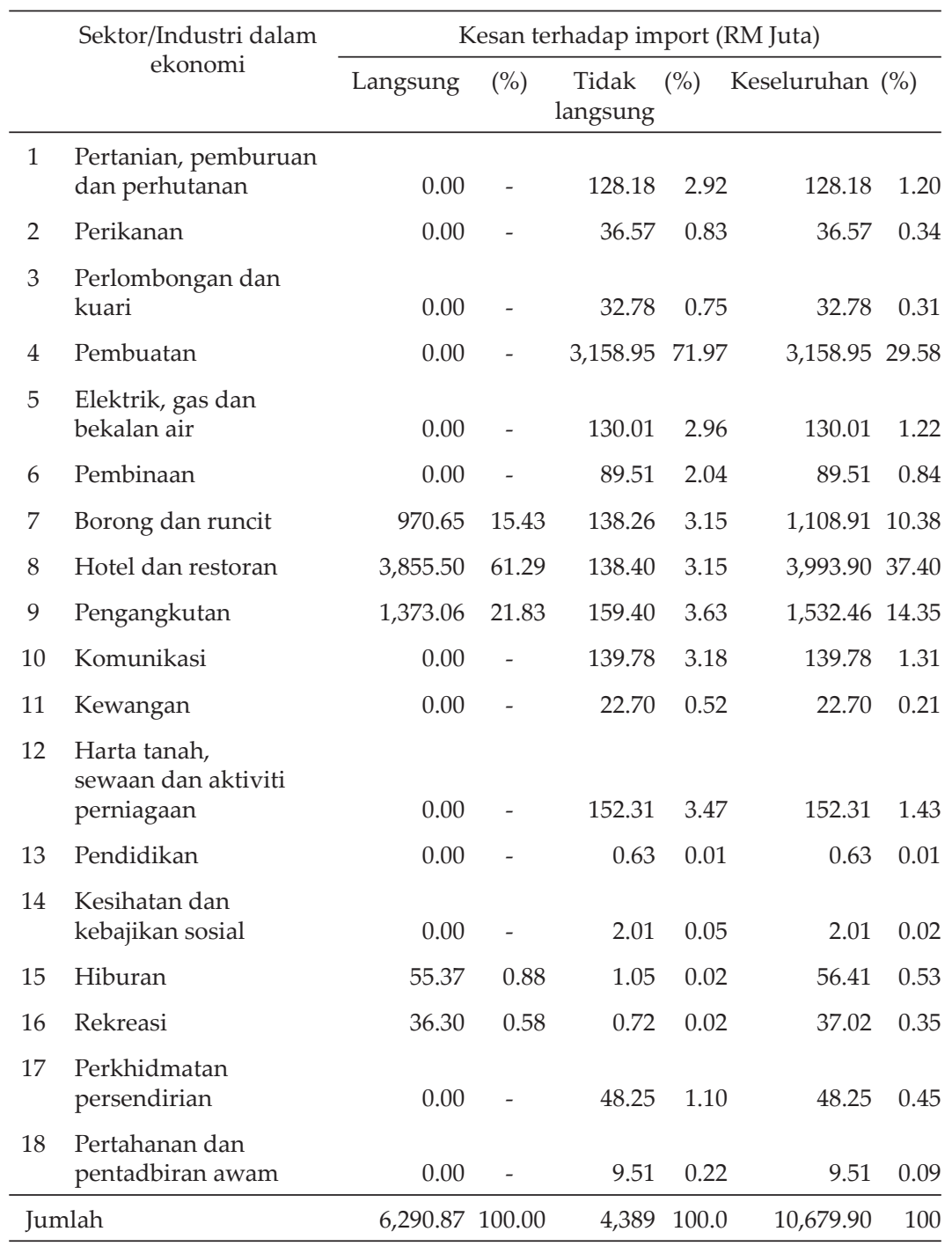




\section{e. Dapatan Keseluruhan Kajian}

Hasil kajian seperti di atas menjelaskan bahawa peningkatan dalam perbelanjaan pelancong telah menyebabkan berlakunya tambahan dalam output, pendapatan buruh, hasil cukai kerajaan dan import bagi barangan dan perkhidmatan dari luar negara. Sungguhpun dorongan peningkatan dalam permintaan akhir adalah dari sektor yang terlibat dengan sektor pelancongan, namun rantaian antara sektor yang wujud dalam sebuah sistem ekonomi telah menyebabkan sektor lain daripada sektor pelancongan juga telah terangsang untuk meningkatkan sama ada output, pendapatan, hasil cukai mahupun nilai importnya. Keadaan ini akhirnya membawa kepada impak ekonomi yang lebih besar dan menyeluruh. Apa yang menarik disini, sungguhpun perbelanjaan pelancongan akhirnya secara keseluruhan menyebabkan import barang dan perkhidmatan dari luar negara meningkat, namum peningkatan import adalah sekitar 20 peratus atau RM10,679.90 juta sahaja daripada perolehan keseluruhan (output) sebanyak RM55,024.95 juta. Keadaan ini menunjukkan masih terdapat lebihan positif daripada pengembangan aktiviti pelancongan. Oleh itu, untuk menjana pertumbuhan ekonomi, pembangunan industri pelancongan adalah satu pilihan yang tepat.

\section{Kesimpulan dan Implikasi Dasar}

Sebagaimana yang dibincangkan industri pelancongan merupakan industri yang mempunyai pelbagai subsektor untuk memenuhi keperluan pelancong yang beranika. Ini bermakna bila berlaku peningkatan dalam perbelanjaan pelancong yang selalunya disebabkan oleh peningkatan dalam ketibaan akan menyebabkan berlakunya peningkatan dalam keluaran, pendapatan buruh, hasil cukai dan pengimportan untuk semua sektor yang berkaitan dengan pelancongan sama ada secara langsung atau tidak langsung. Memandangkan ciri-ciri industri pelancongan yang mempunyai banyak kesan rantaian ini maka pihak kerajaan sewajarnya mengambil inisiatif bagi memajukan industri ini. Malah langkah kerajaan dalam usaha menjadikan pelancongan sebagai antara enjin pertumbuhan ekonomi yang penting adalah berada dilandasan yang betul. Dengan memajukan industri pelancongan banyak sektor-sektor lain yang berkaitan secara langsung atau tidak turut dapat dimajukan.

Seperkara yang harus diberikan perhatian ialah kesan bocoran daripada industri ini. Usaha-usaha boleh diambil untuk mengurangkannya kesan bocoran melalui import. Pengimportan 
khususnya tenaga kerja dari luar tidak sukar untuk dikurangkan. Begitu juga penggunaan peralatan import yang digunakan di hotel-hotel besar seharusnya digantikan oleh produk tempatan. Pihak kerajaan seharusnya menetapkan nisbah minimum peralatan domestik yang mesti digunakan di hotel-hotel dan tempat-tempat pelancongan melalui pemberian insentif yang menarik. Hal ini bukan sahaja dapat mengurangkan pengaliran keluar mata wang negara tetapi dapat mempromosikan barangan buatan negara dan mempamerkan nilai dan budaya yang dimiliki Malaysia yang pada umumnya adalah setanding dengan produk buatan luar negara.

Sebagai kesimpulan kajian ini menjelaskan bahawa peningkatan dalam perbelanjaan pelancong telah merangsang pertumbuhan pelbagai sektor yang berkait sama ada secara langsung mahupun tidak dengan industri pelancongan. Dari segi kesan langsung jelas menunjukkan bahawa sektor yang berkaitan dengan hotel dan restoran menerima impak paling tinggi daripada perbelanjaan pelancong dalam semua aspek yang dikaji (output, pendapatan, hasil cukai dan import). Ini kerana kebanyakan perbelanjaan pelancong (sekitar $30-50 \%$ ) sememangnya dibelanjakan untuk penginapan serta perbelanjaan makan dan minum pelancong sepanjang berada di Malaysia. Jesteru itu, tidak mustahil sektor ini mencatatkan kesan langsung yang tertinggi. Memandang kepada nilai bocoran yang juga tinggi di sektor ini (sekitar 60\%), jelas seperti dinyatakan di atas maka alternatif kepada pencarian produk buatan Malaysia sebagai pengganti adalah langkah yang positif.

Dapatan hasil kajian ini dijangka dapat membantu pihak berkepentingan (stakeholders) untuk merangka strategi yang lebih mantap dalam membangunkan industri pelancongan negara khusus yang melibatkan pengimportan barangan dan perkhidmatan yang diperlukan bagi kegunaan pelancong. Ini harus diberikan perhatian supaya pengaliran mata wang ke luar negara dapat dikurangkan dan seterusnya menjadikan industri pelancongan sebagai industri penjana tukaran mata wang asing dan bukan sebaliknya.

\section{Nota Akhir}

1. Upah bagi setiap tambahan output yang dihasilkan.

2. Penumpuan kepada 18 sektor utama ekonomi Malaysia bertujuan untuk mengelakkan bais dalam penganggaran kerana terlalu banyak sektor yang terlibat. Selain difikirkan adalah 
relaven memandangkan sektor pilihan adalah antara sektor utama dalam pengiraan pendapatan negara yang menjadi amalan Malaysia.

3. Impak kepada guna tenaga mengikut sektoral tidak dapat dilakukan kerana bilangan guna tenaga mengikut sektor tidak dapat diperoleh daripada Jabatan Perangkaan Malaysia. Pendapatan yang dimaksudkan adalah pendapatan kepada buruh. Ini kerana dalam kajian ini ia dikira berasaskan kepada "compensation to employes".

\section{Rujukan}

Archer, B., \& Fletcher, J. (1996). The economic impact of tourism in the Seychelles. Annals of Tourism Research, 23(1), 32-47.

Archer, B. H. (1982). The value of multipliers and their policy implications. Tourism Management, 3(4), 236-41.

Archer, B. H. (1989). Tourism and island economies: Impact analyses. In C. P. Benefits \& Costs. State College. PA: Venture Publishing.

Archer, B. H. (1995). Important of tourism for the economy of Bermuda. Annals of Tourism Research, 22, 918-930.

Fletcher, J. E., \& Archer, B. H. (1991). The development and application of multiplier analysis. In the book: Progress in tourism, recreation and hospitality management.

Frechtling, D. C., \& Horvath, E. (1999). Estimating the multiplier effects of tourism expenditures on a local economy through a regional input-output model. Journal of Travel Research, 37(4), 324-332.

Freeman, D., \& Sultan, E. (1997). The economic impact of tourism in Israel: A multi-regional input-output analysis. Tourism Economic, 3(4), 341-359.

Fretcher, J. E. (1989). Input-output analysis and tourism impact studies. Annals of Tourism Research, 16, 514-529.

Hansen, R. (1970). General equilibrium system. New York: McGrawHill.

Harmston, K. F. (1969). The importance of 1967 tourism to Missouri. Business and Government Review, 10(3), 5-12.

Henry, E. W., \& Deany, B. (1997). The contribution if tourism to the economy of ireland in 1990 and 1995. Tourism Management, 18(8), 535-553.

Kweka, J., Morrisey, O., \& Blake, A. (2003). The economic potential of tourism in Tanzania. Journal of International Development, 15, 335-351.

IJMS 18 (1), 217-238 (2011) 237 
Miller, R. E., \& Blair, P. D. (1985). Input-output analysis: Foundations and extensions. Englewood Cliffs, NJ: Prentice Hall.

Mohammad, N. H. M., Elsadig, M. A., \& Abul Quasem, A. (2009). Does tourism contribute significantly to the Malaysian economy? Multiplier analysis using I-O technique. International Journal of Business and Management, 4(7), 146-159.

Redzuan. O., \& Norlida Hanim, M. S. (2006). Kesesuaian dan keserasian insentif kepada pembangunan industri pelancongan. Dlm. Nor Aini Idris, Ishak Yusoff dan Basri Abdul Talib. (Penyunting), Ekonomi Malaysia ke arah pasca industri. Bangi: Penerbit UKM.

Sinclair, M. T. (1998). Tourism and economic development: A survey. Journal of Development Studies, 34(5), 1-51.

Summary, R. (1987). Tourism contribution to the economy of Kenya. Annals of Tourism Research, 14, 531-540.

Surendra, B. P. (2000). Tourists' consumption pattern and its economic impact in Nepal. New Delhi India: Adroit Publishers.

Tourism Malaysia. (2009). Retrieved from http://www.tourism.gov. my

Zakariah, R., \& Bashir, M. B. (2004). Economic impacts of changing tourist profile in Malaysia: An inter-industial analysis. Asean Journal on Hospitality and Tourism, 3, 29-39. 